Article

\title{
Fluctuating Asymmetry of Craniological Features of Small Mammals as a Reflection of Heterogeneity of Natural Populations
}

\author{
Elena Shadrina ${ }^{1, *}$ and Yakov Vol'pert ${ }^{2}$ \\ 1 Laboratory of Ecosystem Research of Cold Regions, Institute for Biological Problems of Cryolithozone SB \\ Russian Academy of Sciences, Lenin avenue, 41, Yakutsk 677890, Russia \\ 2 Laboratory of Applied Zoology and Bioindication, Research Institute of Applied Ecology, \\ North-Eastern Federal University, Lenin avenue, 1, Yakutsk 677890, Russia; ylv52@mail.ru \\ * Correspondence: e-shadrina@yandex.ru; Tel.: +7-914-225-6989
}

Academic Editor: John H. Graham

Received: 31 August 2016; Accepted: 23 November 2016; Published: 29 November 2016

\begin{abstract}
Fluctuating asymmetry (FA) in nine species of small mammals (Insectivora and Rodentia) was estimated using 10 cranial features (foramina for nerves and blood vessels). The main criterion was the occurrence of the fluctuating asymmetry manifestations (OFAM). A total of 2300 skulls collected in the taiga and forest-tundra of Yakutia (Northeast Asia) were examined. The examined species are characterized by comparable OFAM values in the vast territories of the taiga zone; on the ecological periphery of the range an increased FA level is registered. Asymmetric manifestations in analyzed features are equally likely to occur in males and females. OFAM values in juveniles are higher than in adults; this difference is more pronounced on the periphery of the geographic range. Among juveniles, lower FA levels are observed in individuals that have bred. It can be surmised that the risk of elimination of individuals with high FA levels increases in stressful periods (active reproduction and winter). In conditions that are close to optimal, populations demonstrate relatively homogeneous FA levels, while on the periphery of the area an increase in occurrence of disturbances in developmental stability is observed, which leads, on one hand, to higher average FA for the population and, on the other hand, to heterogeneity of the population in this parameter.
\end{abstract}

Keywords: fluctuating asymmetry; developmental stability; small mammals; population; age; environmental stress

\section{Introduction}

Fluctuating asymmetry (FA) is a widespread biological phenomena, referring to small nondirectional deviations from perfect bilateral symmetry [1]. Fundamental research has shown that FA is a manifestation of disrupted development homeostasis; under normal conditions FA is minimal, but it is increased under any stressful impact [2-5]. Destabilization of individual development is a highly sensitive indicator, allowing one to detect small ontogenetic variations resulting from changes in the environment $[4,6,7]$.

Thanks to this quality, FA is widely used for assessment of the state of populations because it reflects a population's average state of adaptation and co-adaptation [8]. However, it is this quality of FA that often makes it difficult to interpret, since its level reflects the combined negative impacts on the organism but says nothing about specific factors causing it. For example, the results that some authors obtained on the influence of the genotypic component on the FA level are ambiguous [8]. Some studies demonstrate an increase in the FA level with hybridization and greater heterozygosity, while other results show the absence of significant differences, or even a decrease in the FA level [9-12]. The data on inbreeding influence on developmental stability are also inconsistent [13-15]. 
There is the opinion that deviations in developmental stability show only in case of disturbances of genomic coadaptation resulting from inbreeding or distant hybridization $[10,11,15]$. The situation with environmental effects on FA is even more complicated. It is common knowledge that developmental stability is negatively affected by environmental pollution. A decrease in developmental stability under the influence of various chemical contaminants was registered [16-22], as well as in areas affected by industrial facilities [23-26].

In natural populations, developmental stability and, consequently, FA level are affected by both external and internal factors. Among factors that are internal for a population, relatively well studied is FA's dependence on the population cycle phase. In small mammals, an increase in FA can be observed with an increase of the population density during population interruptions. This can be attributed to an increase in social stress; this has been shown both in natural populations and by experiment $[5,27]$.

Among the abiotic factors known to influence FA level is ambient temperature. Its effect is especially pronounced in poikilotherms: in natural populations of the sand lizard and in an experiment, the highest developmental stability and, as a consequence, a low FA level were characteristic for optimal temperatures, and destabilization of ontogeny was observed to increase with distance from the optimum zone [5]. Similar data were obtained in studies into the effect of temperature on various species of insects and fishes [28-32]. Despite the fact that homoiotherms maintain a constant internal temperature, the stability of their development can also be affected by temperature; a decrease in developmental stability during the prenatal and early postnatal stages of ontogeny was found in mice and rats exposed to high and low temperatures [33].

It can be assumed that populations from the periphery of the geographic range of the species, where conditions are far from optimal, should be characterized by increased FA levels resulting from the negative impact of environmental conditions.

There are very few studies testifying in favor of this hypothesis. An increase in FA level was observed on the periphery of the geographic range in some species, such as the sand lizard [5] and the taiga species of small mammals [25]. Among the biotic factors that affect the FA level which may also be noted is the quality of habitat [34-36]; in particular, habitat fragmentation has a negative impact on developmental stability $[35,36]$.

At the moment, many works on FA in animals are based on experimental data, while the study of ecological factors in nature receives much less attention. This is explained by objective difficulties associated with the study of natural populations: problems with collecting the material, issues of representativeness of samples, as well as analysis of multicomponent influence. As a result, along with studies substantiating quite high dependence of FA on environmental conditions, there are works that do not support this dependence, or even invalidate it [37-39]. Graham and others [8], in their review, reasonably noted that in such studies, representativeness of samples is of great importance, as well as the number of analyzed features and the choice of features to be analyzed, since not all features show adequate responses to stressful impacts.

When comparing natural populations and evaluating stressful impacts, researchers, as a rule, look at the average value for a population or a group, which reflects the general state of the population or a group of individuals in this population, while natural populations are heterogeneous in many parameters and, in our opinion, heterogeneity of individuals with respect to FA level is not random. It is known that while FA manifestations themselves do not affect individual viability, they do, to some extent, reflect the presence of various disorders in the organism that affect its ability to survive. For example, Naugler and Leech [40] showed that the higher the degree of asymmetry of the tarsal segment of legs in caterpillars of some moths, the lower the survivability of the individual. According to a number of authors, a certain level of developmental stability is maintained by natural selection, in particular by lowered reproduction of asymmetric individuals [41]. In many species females prefer males with symmetrical color patterns $[42,43]$. Supposedly, the explanation is that the FA level may reflect the individual ability to withstand a wide spectrum of environmental influences, so sexual ornamentation, in addition to attracting females, conveys information about the male quality. 
Some opine that in insects and small mammals, asymmetrical individuals are more susceptible to elimination by predators [44,45]. Thus, different qualities of individuals that comprise a natural population are reflected in different susceptibilities to stress, and differences in elimination risk and in the measure of disturbance in developmental homeostasis (the latter being reflected in FA).

Heterogeneity of natural populations makes it difficult to assess the population state by FA level, as the FA level of the population will inevitably depend on the sample size, the physiological and social state of individuals comprising the population, the age composition of the population at the moment, and the force of influence of a complex of ecological factors. At the present time, a scarcity of data on intrapopulation variability of the FA level in natural conditions is evident. This issue is very relevant both for studying variability of a feature in natural conditions and for assessment of technogenic influence, which is often superimposed on natural factors.

The aim of our research was to study intra- and interpopulation variability in FA level in order to evaluate the influence of the geographical zones, habitat conditions, and sex and age structure of a population on the developmental homeostasis of small mammals (Insectivora and Rodentia) living in the severe natural and climatic conditions of the northern taiga.

The material was collected in the territory of Yakutia, a vast region in Northeast Asia, which takes up about one-sixth of the territory of Russia and is known for its extreme climatic conditions. The Pole of Cold of the northern hemisphere, Oymyakon, is located there; the whole area is characterized by a sharply continental climate with long, cold winters and a short vegetation period (Table 1, Figure 1).

Table 1. Characteristics of natural and climatic conditions of the study area.

\begin{tabular}{|c|c|c|c|c|c|}
\hline No. & Point & $\begin{array}{c}\text { Type of } \\
\text { Vegetation }\end{array}$ & Climatic Zone & $\begin{array}{c}\text { Summers, } \\
\text { Period (Days) }\end{array}$ & $\begin{array}{l}\text { Suitability for } \\
\text { Small Mammals }\end{array}$ \\
\hline 1 & Southern Yakutia & Middle taiga & \multirow{5}{*}{$\begin{array}{l}\text { Temperate, } \\
\text { sharply } \\
\text { continental } \\
\text { climate }\end{array}$} & 75 & \multirow{5}{*}{$\begin{array}{l}\text { Near the optimum for } \\
\text { the taiga species }\end{array}$} \\
\hline 2 & Southern Yakutia & Middle taiga & & 95 & \\
\hline 3 & Central Yakutia & Middle taiga & & 95 & \\
\hline 4 & Western Yakutia & Middle taiga & & 95 & \\
\hline 5 & Western Yakutia & Northern taiga & & 78 & \\
\hline 6 & Western Yakutia & Tundra-forest & \multirow{4}{*}{$\begin{array}{l}\text { Subarctic } \\
\text { climate }\end{array}$} & 60 & \multirow{3}{*}{$\begin{array}{l}\text { Northern periphery of } \\
\text { the taiga species range }\end{array}$} \\
\hline 7 & Northern Yakutia & Tundra-forest & & 70 & \\
\hline 8 & Northeastern Yakutia & Tundra-forest & & 55 & \\
\hline 9 & Central Verchoyanie & Mountain taiga & & 60 & $\begin{array}{l}\text { Ecological periphery of } \\
\text { the taiga species range }\end{array}$ \\
\hline
\end{tabular}

The territory of Yakutia spans over three climate zones, temperate, subarctic, and arctic, but our research covers mainly the first two zones, because the taiga species of small mammals, as a rule, do not penetrate into the arctic zone. Most of the territory belongs to the taiga zone. Small mammal populations there are formed under the influence of the hard pressure of abiotic and biotic factors, and this is reflected in the poor composition of the communities-as a rule, they are represented by 15-22 species, and in any separate biotope, by five to 10 species [46]. The communities are dominated by the species most undemanding and adapted to the northern conditions; in the taiga it is the northern red-backed (Clethrionomys rutilus) and grey red-backed voles ( $\mathrm{Cl}$. rufocanus), the root vole (Microtus oeconomus), the wood lemming (Myopus schisticolor), and Laxmann's (Sorex caecutiens), and tundra (S. tundrensis) shrews. In the tundra, it is the Siberian brown (Lemmus sibiricus) and Arctic (Dicrostonyx torquatus) lemmings. Living in such conditions is reflected in the population reproduction parameters: intensive reproduction of juveniles, high fertility, and rapid change of generations [46]. Nevertheless, even in such harsh conditions, small mammals can successfully survive and achieve high abundance levels. 


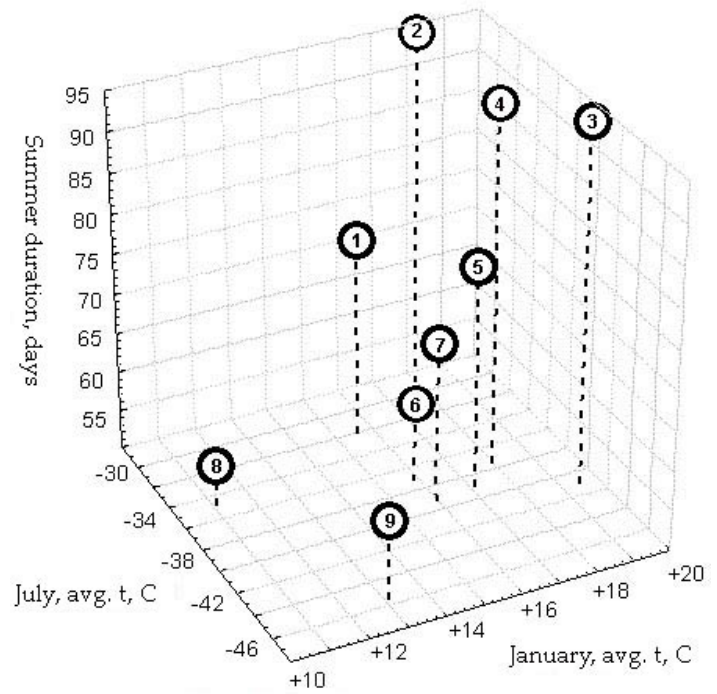

Figure 1. Some climatic characteristics of the studied sites. Note 1: summer here is interpreted as the period with no negative temperatures, ${ }^{\circ} \mathrm{C}$; Note 2 : the numbers of the sites are in accordance with Table 1.

Thus, this territory is a convenient "testing ground" for conducting studies, because due to its ecological and geographical conditions, this is the northern border of the geographic range for many representatives of Micromammalia, and, as a consequence, their populations are characterized by tense relations with the environment. It seems logical to assume that the tensions in the "organism-environment" system leave their mark on the stability of individual development.

\section{Materials and Methods}

As objects of research we chose rodents and insectivores, collected in undisturbed habitats of taiga and forest-tundra in Yakutia. For the analysis of the FA level, the northern red-backed (Clethrionomys rutilus) and grey red-backed (Cl. rufocanus) voles, the root vole (Microtus oeconomus), wood lemming (Myopus schisticolor), Laxmann's (Sorex caecutiens), and tundra (S. tundrensis) and Siberian large-toothed (S. daphaenodon) shrews were chosen.

That several species were examined was dictated by the goal of the study, the analysis of FA in natural populations of related species. The species covered were selected due to the characteristics of small mammal communities of the region. For analysis we used the species playing a significant role in communities, i.e., dominants or subdominants ( $>15 \%$ of a community in a given habitat) that are widely distributed over the studied territory. In addition, in a number of cases we used supplementary data on species that play a significant role in communities in certain areas: the narrow-headed vole (Microtus gregalis) and the taiga shrew (Sorex isodon).

For the analysis we used materials collected in different regions of Yakutia by us (sites 1-8) and our colleagues (site 9). Different sample sizes are explained by the availability of the material. Abundance levels in all cases (except for the wood lemming, which is specifically pointed out in the text) were similar, which rules out that FA was influenced by the social factor of population peak. In all cases small mammals were collected using a standardized method (cone-traps), so the data on relative abundance from all the sites are intercomparable.

For assessment of developmental stability disorders in mammals we examined cranial features (foramina for nerves and blood vessels) using the method proposed by Zakharov et al. [47] (Figure 2). 


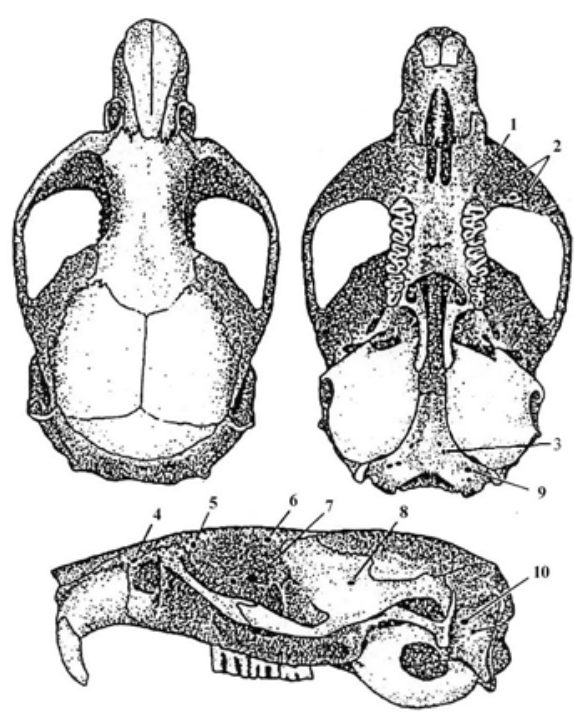

(a)

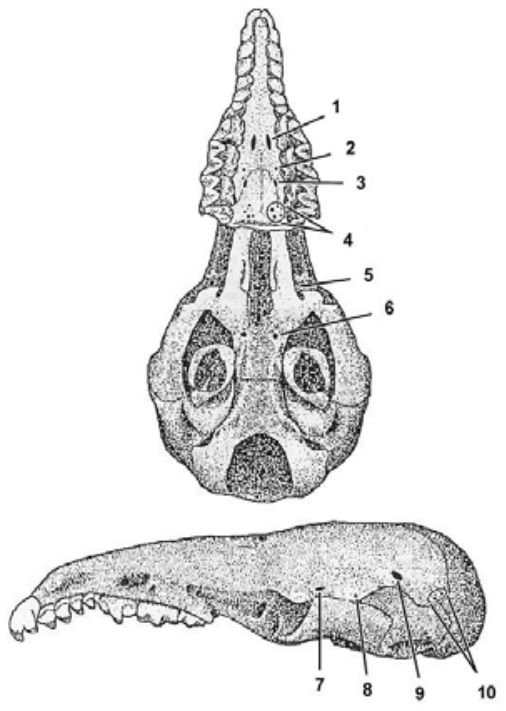

(b)

Figure 2. The layout of features selected for assessment of FA (fluctuating asymmetry) in small mammals [47]. (a) Voles and lemmings, the number of foramina on: 1, foramen diastemae; 2, foramen basis processus; 3 , foramen basioccipitale; 4 , foramen hypoglossum accessories internus; 5 , foramen suprainfraorbitalis; 6 , foramen supraorbitalis anterior; 7 , foramen supraorbitalis posterior; 8 , foramen ethmoideum accessory anterior; 9, foramen squamosum; 10, foramen mastoideum accessories; (b) shrews, the number of foramina on: 1, foramen palatinum anterior; 2, foramen palatinum posterios accessories minor; 3 , foramen palatinum posterior; 4 , foramen palatinum laminae; 5 , foramen accessories canalis pterigoideum; 6 , foramen basiosphenoidalis lateralis; 7 , foramen parietale anterior; 8 , foramen parietale media; 9 , foramen parietale posterior; 10 , foramen parietale corner.

There is no correlation between the analyzed features; their phenotypic expression does not change with age [47]. This method was developed for European species of small mammals: Clethrionomys glareolus, Microtus arvalis, Sorex araneus [47]. However, our previous studies have proved that it is also applicable to the species that we examined [25,48].

Each of analyzed features can consist of zero to three foramina. Foramina were counted on the left and right sides of the skull. The expression of a feature was considered asymmetric if the number of foramina differed on either side (zero to one, one to two, and so on). What was taken into account was not the exact difference in the number of foramina but the fact of expression of asymmetry. The magnitude of fluctuating asymmetry was estimated by the occurrence of asymmetry manifestations per individual, with each asymmetric feature weighing one point and each symmetric feature weighing zero points. As an individual measure of FA we used the occurrence of the fluctuating asymmetry manifestation (OFAM), expressed as a decimal fraction ratio of asymmetric features to the total number of features examined [47].

$$
\mathrm{OFAM}=\frac{A}{m}
$$

where OFAM is the occurrence of the fluctuating asymmetry manifestation; $A$, the number of asymmetric features; $m$, the total number of the examined features.

Thus, hypothetically, we can characterize each individual with an OFAM value from 0 (if the number of foramina is equal on both sides in each of these points) to 1 (if the number of foramina coincides in no point), though in reality extreme OFAM values $(0$ and 1$)$ were not registered. Zakharov et al., who developed the method [47], believe that a value of less than 0.35 in rodents and less than 0.20 in shrews indicates minimal deviations from the normal state. Our previous studies allow us to support this opinion $[25,48]$. For statistical treatment of the material standard methods were used. As a measure of FA population level the arithmetic mean of OFAM was used. For a pairwise 
comparison of samples we used Student's $t$-test with a correction for different sample sizes; for multiple comparison, with the Bonferroni correction. To assess the significance of correlations Spearman's nonparametric rho was calculated. To analyze the influence of different factors on the FA level we used regression analysis.

For the analysis of age differences, the age of individuals of Clethrionomys genus was determined by the degree of development of molar roots [49]. In the grey red-backed vole four age groups were distinguished: adults and juveniles of the age of one, two and three to four months. The age of voles of Microtus genus and the wood lemming was determined using a complex of cranial features-the degree of fusion of the cranial sutures and development of ridges. Adult (ad) and juvenile (juv) individuals were distinguished. The age of shrews was determined by the degree of wear of the intermediate teeth and the development of the cranial sutures.

The total of 2300 skulls of small mammals was analyzed. The volume and characteristic of the material examined are presented in the Table 2.

Table 2. The characteristics of the examined material.

\begin{tabular}{|c|c|c|c|c|c|c|c|c|c|c|}
\hline \multirow{3}{*}{ No. } & \multirow{3}{*}{ Region } & \multirow{3}{*}{ Species } & \multirow{2}{*}{\multicolumn{3}{|c|}{ Study Goal * }} & \multirow{3}{*}{$n$} & \multicolumn{4}{|c|}{ The Number of: } \\
\hline & & & & & & & \multicolumn{2}{|l|}{ Ad } & \multicolumn{2}{|l|}{ Juv } \\
\hline & & & G & $\mathrm{S}$ & A & & $0^{7}$ & q & $0^{7}$ & q \\
\hline \multirow{6}{*}{1} & \multirow{6}{*}{$\begin{array}{l}\text { Southern } \\
\text { Yakutia }\end{array}$} & Clethrionomys rutilus & + & & + & 63 & 14 & 12 & 22 & 15 \\
\hline & & Cl. rufocanus & + & & & 7 & 1 & 1 & 2 & 3 \\
\hline & & Myopus schisticolor & + & + & + & 128 & 20 & 34 & 29 & 45 \\
\hline & & Sorex caecutiens & + & & & 128 & 8 & 9 & 90 & 21 \\
\hline & & S. isodon & + & & & 12 & 1 & - & 8 & 3 \\
\hline & & S. daphaenodon & + & & & 6 & - & - & 4 & 2 \\
\hline \multirow{4}{*}{2} & \multirow{4}{*}{$\begin{array}{l}\text { Southern } \\
\text { Yakutia }\end{array}$} & Clethrionomys rutilus & + & + & + & 125 & - & 1 & 65 & 59 \\
\hline & & Microtus oeconomus & + & & & 53 & 11 & 6 & 21 & 15 \\
\hline & & Sorex caecutiens & + & & & 36 & 2 & - & 18 & 16 \\
\hline & & S. tundrensis & + & & & 16 & 1 & 1 & 5 & 9 \\
\hline \multirow{5}{*}{3} & \multirow{5}{*}{$\begin{array}{l}\text { Central } \\
\text { Yakutia }\end{array}$} & Clethrionomys rutilus & + & + & & 107 & 29 & 21 & 30 & 27 \\
\hline & & Microtus oeconomus & + & + & & 48 & - & - & 28 & 20 \\
\hline & & M. gregalis & + & & & 24 & - & - & 12 & 12 \\
\hline & & Sorex caecutiens & + & & & 12 & - & - & 7 & 5 \\
\hline & & S. tundrensis & + & & & 20 & - & - & 10 & 10 \\
\hline \multirow{5}{*}{4} & \multirow{5}{*}{$\begin{array}{l}\text { Western } \\
\text { Yakutia }\end{array}$} & Clethrionomys rutilus & + & & & 16 & - & - & 8 & 6 \\
\hline & & Microtus oeconomus & + & + & + & 180 & 28 & 23 & 74 & 55 \\
\hline & & Microtus gregalis & + & & & 23 & - & - & 11 & 12 \\
\hline & & Sorex caecutiens & + & & & 18 & - & - & 10 & 8 \\
\hline & & S. tundrensis & + & & & 12 & - & - & 6 & 6 \\
\hline \multirow{6}{*}{5} & \multirow{6}{*}{$\begin{array}{l}\text { Western } \\
\text { Yakutia }\end{array}$} & Clethrionomys rutilus & + & + & & 51 & 5 & 4 & 21 & 21 \\
\hline & & Cl. rufocanus & + & & & 25 & - & - & 12 & 13 \\
\hline & & Microtus oeconomus & + & & & 30 & 1 & 2 & 13 & 12 \\
\hline & & Sorex caecutiens & + & + & & 46 & 2 & - & 23 & 21 \\
\hline & & S. tundrensis & + & + & & 42 & - & - & 22 & 20 \\
\hline & & S. daphaenodon & + & + & & 49 & 1 & 1 & 25 & 22 \\
\hline \multirow{4}{*}{6} & \multirow{4}{*}{$\begin{array}{l}\text { Western } \\
\text { Yakutia }\end{array}$} & Clethrionomys rutilus & + & & & 28 & 2 & 1 & 15 & 10 \\
\hline & & Cl. rufocanus & + & & & 14 & - & - & 8 & 6 \\
\hline & & Microtus oeconomus & + & & & 8 & - & - & 3 & 5 \\
\hline & & Sorex caecutiens & + & & & 12 & 1 & - & 8 & 3 \\
\hline \multirow[b]{2}{*}{7} & \multirow{2}{*}{$\begin{array}{l}\text { Northern } \\
\text { Yakutia }\end{array}$} & S. caecutiens & + & + & & 39 & 1 & - & 24 & 14 \\
\hline & & S. tundrensis & + & & & 48 & - & - & 27 & 21 \\
\hline & & Clethrionomys rutilus & + & + & + & 84 & 22 & 26 & 20 & 16 \\
\hline & & Cl. rufocanus & + & & & 34 & 13 & 11 & 4 & 6 \\
\hline & & Myopus schisticolor & + & + & + & 173 & 72 & 75 & 10 & 16 \\
\hline 8 & Northeastern & Microtus oeconomus & + & + & + & 208 & 53 & 37 & 61 & 57 \\
\hline & & Sorex caecutiens & + & & + & 145 & 8 & 3 & 78 & 56 \\
\hline & & Sorex tundrensis & + & & + & 62 & 3 & - & 35 & 24 \\
\hline & & S. daphaenodon & + & & & 16 & - & - & 8 & 8 \\
\hline & Central & Clethrionomys rutilus & + & & + & 68 & 10 & 17 & 20 & 21 \\
\hline 9 & Verchoyanie & Sorex caecutiens & + & & & 83 & 9 & 5 & 39 & 30 \\
\hline
\end{tabular}

Note: in sites 1, 3, 4, 6, 7, and 9 the material was collected during one summer; in sites 2 and 5, two summers; in site 8, three summers. ${ }^{*}$ represents assessment of FA variability: G, geographic; S, sex; A, age. Ad: Adult; Juv: juvenile. 


\section{Results and Discussion}

\subsection{Geographical and Zonal Differences in FA Level}

We evaluated the FA level of taiga species of small mammals in nine sites in the territory of Yakutia (Figure 3). Points 1-5 belong to the typical taiga zone, which can be considered as optimal for the species we covered: the northern and grey red-backed voles, the root vole, the narrow-headed vole, the wood lemming, and Laxmann's, tundra, taiga, and Siberian large-toothed shrews. Sites 1-4 are characterized by more favorable conditions (middle taiga), and site 5 belongs to the north taiga and is characterized by somewhat harsher ecological conditions for small mammals. Sites $6-8$ belong to the forest-tundra; this is where the northern bounds of many species' geographic range lie, and site 9 (Central Verkhoyan'e) is in the mountain taiga, where the distribution of the forest species of small mammals is restricted by the elevation of $1100 \mathrm{~m}$, the altitudinal limit of the forest vegetation zone. Thus, this altitude can be considered the ecological periphery of the area of the taiga species.

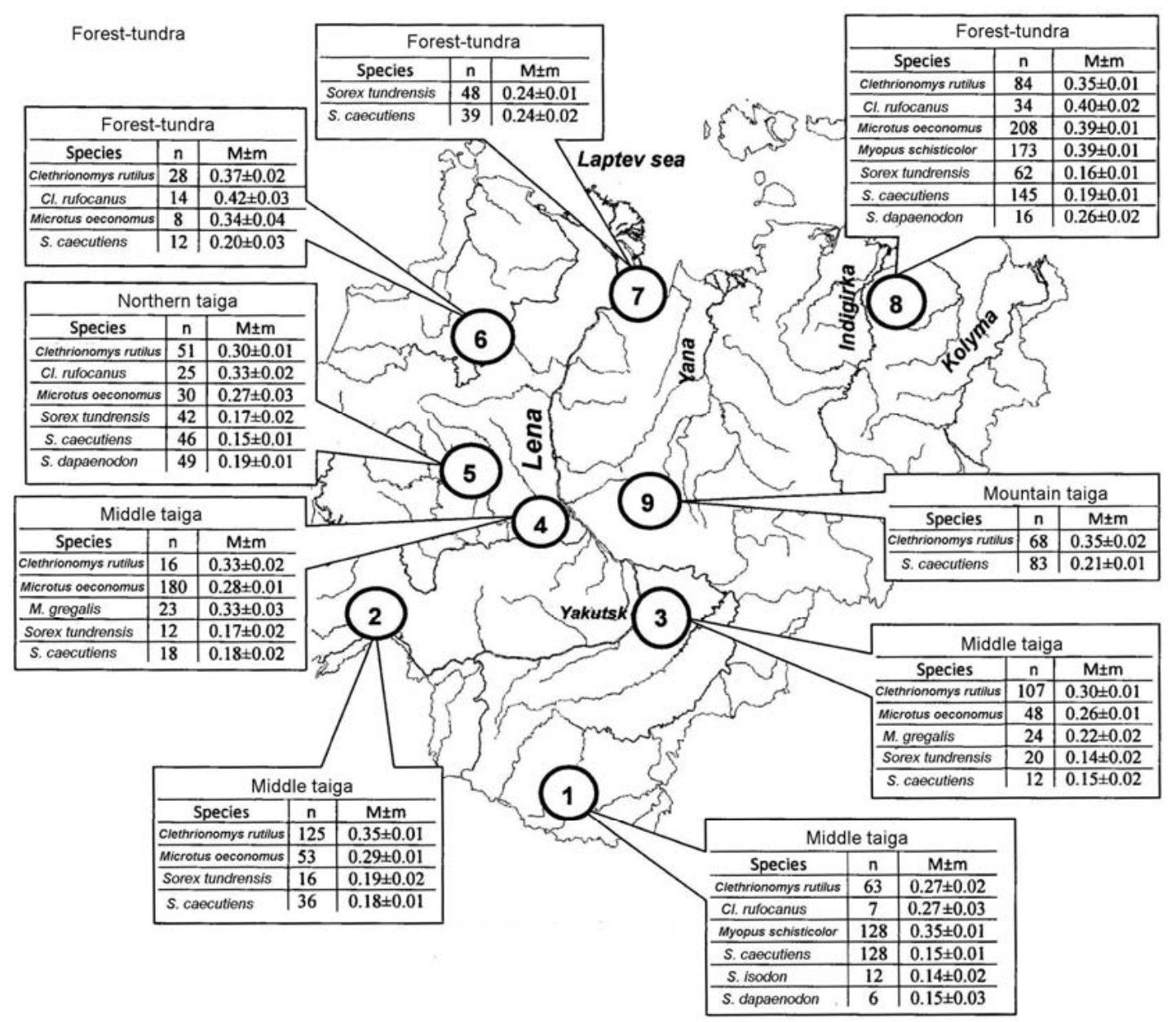

Figure 3. FA levels in small mammals in undisturbed habitats of Yakutia. Note 1: The characteristic of sites 1-9 is given in Table 1; the distribution of species by sex and age groups, in Table 2. Note 2: In the tables: $n$, the number of individuals; $M$, arithmetic mean of OFAM (occurrence of the fluctuating asymmetry manifestations); $m$, error.

On the whole, in the studied territory OFAM varied over a wide range. In rodents, the average population value varied within $0.25-0.35$; in insectivores, it varied within $0.15-0.20$ (Figure 2 ). We think that the differences in FA level between the rodents and insectivores are explained by the differences in their skull structure. The examined cranial features of these two groups (Microtina and Soricidae) are 
not homologous, so they are unlikely to exhibit similar values. Similar OFAM levels were registered by Zakharov et al. in related species in natural biotopes of European Russia, i.e., in significantly more favorable climatic conditions. Therefore, we suppose that, for indigenous species, the taiga zone can be viewed as the optimal environment, which is characterized by minimal deviations from the normal FA level. However, these data are the averages, without taking into account the age composition of the samples, topographic features, and climate conditions. These data reflect only one fact: that it is impossible to analyze the state of the population without first considering inter- and intrapopulation variability.

For the northern populations (forest tundra), the averaged data on OFAM in rodents varied within $0.35-0.40$; in shrews, it varied within $0.16-0.26$ (Figure 3). The comparison of FA levels of small mammals living in forest-tundra in different regions of Yakutia revealed similar values.

In the forest-tundra of the Indigirka River Valley, disturbances were registered in most mass species, but it should be noted that among the rodents, the relatively low levels of disturbances are characteristic of the northern red-backed vole, the most ecologically flexible species among those considered, and for the tundra shrew, whose geographic range northern bounds lie far to the north.

It is interesting to compare the FA levels in the same site (for example, site 8) in insectivore species whose geographic range bounds differ. Out of the three species of shrews collected in the forest-tundra in the lower reaches of the Indigirka River, the tundra shrew settles the furthest north, somewhat to the south ends of the area of the Laxmann's shrew, and for the Siberian large-toothed shrew, this point is actually an extreme northern outpost, which is reflected in the different OFAM values (Figure 4). Note that differences in OFAM values between the tundra and Laxmann's shrews do not reach a statistically significant level, and for both species the FA level is statistically significantly lower than in the Siberian large-toothed shrew $(t=3.54, d f=76, p<0.001$ for the pair "tundra shrew-Siberian large-toothed shrew" and $t=3.13, d f=159, p<0.01$ for the pair "Laxmann's shrew-Siberian large-toothed shrew").

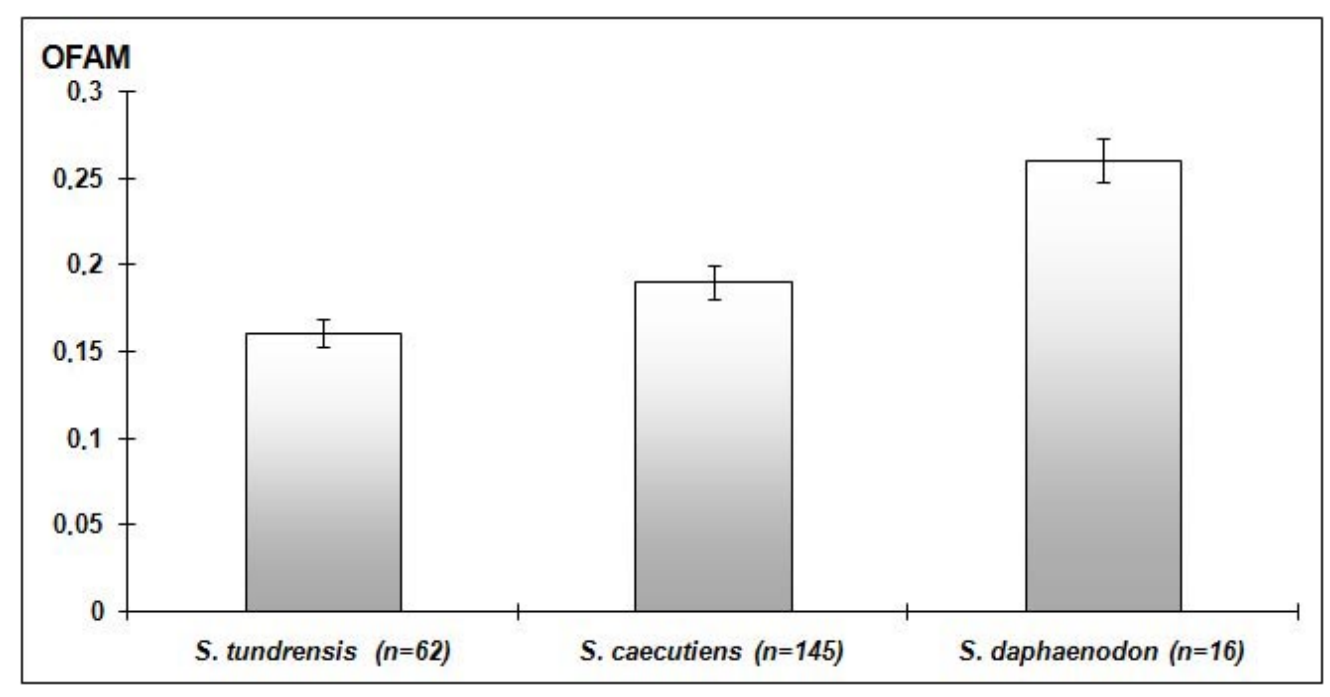

Figure 4. Differences in OFAM in three shrew species in the forest-tundra. Note: here and below (Figures 5-8) the error bar represents relative error.

Moving up to the mountains, one can also note an increase in the occurrence of deviations in developmental stability, associated with the altitudinal climatic zonality. It is known that in the north, even relatively small heights have an adverse impact on the biota. For example, in the Verkhoyan'e mountains, the border of the forest vegetation zone is at an altitude of about $1000 \mathrm{~m}$ above sea level. Communities of small mammals there are characterized by poor species composition, and out of typical taiga species only two of the most eurytopic species, the northern red-backed vole and Laxmann's 
shrew, can be found high in the mountains. Note that FA levels in the Laxmann's shrew and the northern red-backed vole in the mountains are increased, but the differences between the animals living in the forest zone and in the subalpine shrub zone do not reach a statistically significant level (Figure 5). It is possible that the absence of significant differences between the two vegetation zones in the mountains is explained by the specifics of collecting the material: in the subalpine shrub zone proper, the population of small mammals is very sparse, and traps were set not far from the bounds of the forest zone, so it is conceivable that some of the animals collected in the subalpine shrub zone are migrants from the forest zone. Therefore, in this case we are talking not about significant differences, but only about a tendency that needs further study.

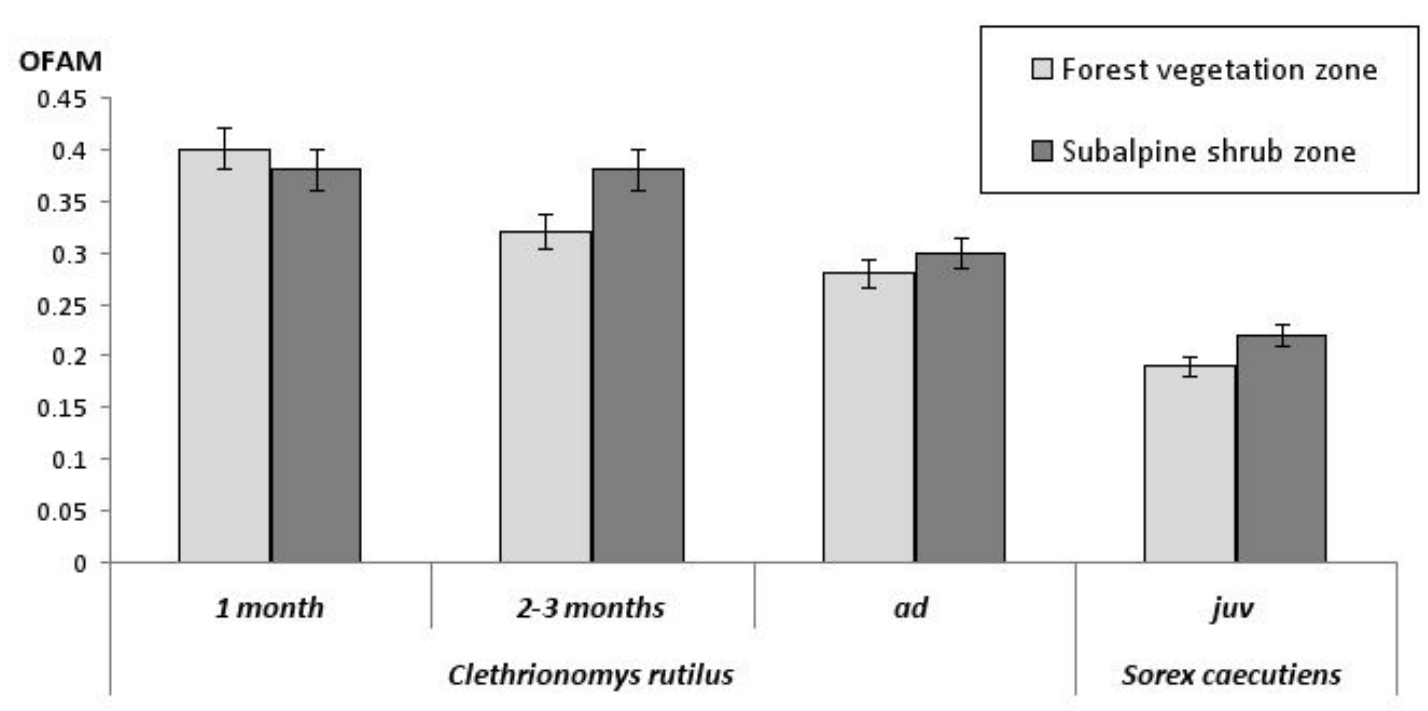

Figure 5. OFAM in the Laxmann's shrew (Sorex caecutiens) and the northern red-backed vole (Clethrionomys rutilus) in the mountain taiga of the Central Verchoyany'e.

A comparison of FA levels in voles and shrews showed that, for the examined features within the optimal part of the geographic range and in comparable abundance levels within the orders Insectivora and Rodentia, FA is characterized by similar levels. To analyze the environmental influence on FA levels of small mammals, we examined major factors that determine favorable conditions in the north: the geographical latitude of the sites where the material was collected, the climate conditions (temperate or subarctic zone, average summer and winter temperatures, the length of the frost-free period), and the vegetation zone. Sex and age groups and species affinity were taken into account. As one would expect, a high correlation was found between all climatic parameters and between climatic parameters and climate and vegetation zones and optimality for small mammals. For all of these parameters, a good correlation was found with the latitude of the regions, which is logical: the latitude within the region (Eastern Siberia) determines the climatic characteristics of the area, and they, in turn, determine the type of vegetation. Regression analysis showed a high dependence of the FA level on analyzed factors ( $p<0.05$ for the combined effect); the main contribution to the dependence is made by the latitude of the location (regression coefficient is $0.65, p<0.05$ ). In addition, a significant contribution is made by the age of the individual (further discussion below), whereas the species affinity and gender of the individual had virtually no effect on the FA level.

\subsection{Intrapopulation Variability in Developmental Stability Values}

\subsubsection{Sex-Related Differences}

Previous studies have shown that, for the examined features, the occurrence of FA manifestations does not depend on the age and sex of the individual [47]. To verify this assumption and to explore the possibility of sexual dimorphism in the FA level in populations of rodents and shrews, we selected 
only representative samples (with $n>20$ for either gender). To rule out the probable influence of other factors, each sample included individuals collected during one reproductive season and that were of the same age and reproductive status (Table 3). Our data also showed no significant difference between males and females; the trend is observed quite strictly in all examined species of small mammals and in all age groups (provided a sufficient sample size). Even in cases when the differences between males and females seem considerable, e.g., in juveniles of the root vole from site 5 (Western Yakutia), they do not reach a statistically significant level. Additionally, notice the absence of a common trend in differences: in some cases the FA is higher in males; in others, it is higher in females. Regression analysis of the array of data on all species also showed a complete absence of statistically significant relationships between the FA level and the sex of the individual, with a regression coefficient of 0.02 . This is why below, in the discussion, we will use the average data, including males and females.

Table 3. FA (Fluctuating asymmetry) anifestations in different age and sex groups of small mammals.

\begin{tabular}{|c|c|c|c|c|c|c|}
\hline \multirow{3}{*}{ Species } & \multirow{3}{*}{ Region } & \multirow{3}{*}{ Age } & \multicolumn{4}{|c|}{$\begin{array}{l}\text { OFAM (occurrence of the fluctuating } \\
\text { asymmetry manifestations) }\end{array}$} \\
\hline & & & \multicolumn{2}{|r|}{ Males } & \multicolumn{2}{|r|}{ Females } \\
\hline & & & $n$ & $M \pm m$ & $n$ & $M \pm m$ \\
\hline \multirow{6}{*}{ Clethrinomys rutilus } & Southern Yakutia & juv & 65 & $0.35 \pm 0.01$ & 59 & $0.35 \pm 0.02$ \\
\hline & \multirow{2}{*}{ Central Yakutia } & $\mathrm{ad}$ & 29 & $0.25 \pm 0.02$ & 21 & $0.26 \pm 0.02$ \\
\hline & & juv & 30 & $0.31 \pm 0.01$ & 27 & $0.29 \pm 0.02$ \\
\hline & Western Yakutia & juv & 21 & $0.28 \pm 0.03$ & 21 & $0.34 \pm 0.02$ \\
\hline & Northeastern Yakutia & $\mathrm{ad}$ & 22 & $0.34 \pm 0.02$ & 26 & $0.32 \pm 0.03$ \\
\hline & Central Verchoyanye & juv & 20 & $0.38 \pm 0.03$ & 21 & $0.39 \pm 0.03$ \\
\hline \multirow{3}{*}{ Myopus schisticolor } & \multirow{2}{*}{ Southern Yakutia } & $\mathrm{ad}$ & 20 & $0.35 \pm 0.01$ & 34 & $0.34 \pm 0.02$ \\
\hline & & juv & 29 & $0.36 \pm 0.03$ & 45 & $0.34 \pm 0.03$ \\
\hline & Northeastern Yakutia & $\mathrm{ad}$ & 57 & $0.36 \pm 0.01$ & 47 & $0.37 \pm 0.02$ \\
\hline \multirow{5}{*}{ Microtus oeconomus } & Central Yakutia & juv & 28 & $0.27 \pm 0.02$ & 20 & $0.25 \pm 0.03$ \\
\hline & \multirow{2}{*}{ Western Yakutia } & $\mathrm{ad}$ & 28 & $0.29 \pm 0.02$ & 23 & $0.30 \pm 0.04$ \\
\hline & & juv & 74 & $0.31 \pm 0.03$ & 55 & $0.32 \pm 0.02$ \\
\hline & \multirow{2}{*}{ Northeastern Yakutia } & ad & 53 & $0.35 \pm 0.02$ & 37 & $0.34 \pm 0.01$ \\
\hline & & juv & 61 & $0.44 \pm 0.04$ & 57 & $0.41 \pm 0.03$ \\
\hline \multirow{4}{*}{ Sorex caecutiens } & Southern Yakutia & juv & 90 & $0.15 \pm 0.01$ & 21 & $0.16 \pm 0.02$ \\
\hline & Western Yakutia & juv & 23 & $0.15 \pm 0.03$ & 21 & $0.15 \pm 0.04$ \\
\hline & Northeastern Yakutia & juv & 78 & $0.20 \pm 0.03$ & 56 & $0.18 \pm 0.01$ \\
\hline & Central Verchoyanye & juv & 39 & $0.22 \pm 0.03$ & 30 & $0.20 \pm 0.02$ \\
\hline \multirow{2}{*}{ Sorex tundrensis } & Western Yakutia & juv & 22 & $0.18 \pm 0.03$ & 20 & $0.20 \pm 0.02$ \\
\hline & Northeastern Yakutia & juv & 27 & $0.16 \pm 0.02$ & 21 & $0.19 \pm 0.03$ \\
\hline Sorex daphaenodon & Western Yakutia & juv & 25 & $0.18 \pm 0.03$ & 22 & $0.20 \pm 0.01$ \\
\hline
\end{tabular}

\subsubsection{Age-Related Differences}

Comparison of the FA level in adult and juvenile individuals revealed that, in most cases, OFAM in adults is lower than in juveniles (Table 4). Note that the difference between juvenile and adult individuals in different regions and at different times was pronounced to varying extents. Within the taiga zone, the FA level was almost the same in juveniles and adults, whereas in the forest-tundra, as a rule, the differences reached a statistically significant level (Table 4).

Following the age-related changes in the FA level in insectivores is difficult due to the aforementioned aspects of their population age structure: there is an extremely low amount of overwintered individuals. Relatively large samples from the forest-tundra of the lower reaches of the Indigirka River demonstrate some differences (not unlike those in voles) in the occurrence of asymmetry manifestations between juvenile and adult individuals. 
Table 4. Differences in FA level between the juvenile and adult rodents in the middle taiga and forest-tundra.

\begin{tabular}{|c|c|c|c|c|c|c|}
\hline \multirow{3}{*}{ Region } & \multirow{3}{*}{ Species } & \multicolumn{4}{|c|}{ OFAM, in Age Group } & \multirow{3}{*}{$\begin{array}{c}t \text {-Test, } \\
\text { Significance } \\
\text { of Difference }\end{array}$} \\
\hline & & \multicolumn{2}{|c|}{ Juv } & \multicolumn{2}{|r|}{ Ad } & \\
\hline & & $n$ & $M \pm m$ & $n$ & $M \pm m$ & \\
\hline \multirow{4}{*}{ Middle taiga } & Clethrionomys rutilus & 57 & $0.29 \pm 0.02$ & 50 & $0.25 \pm 0.02$ & \multirow{4}{*}{$0-1.46 *$} \\
\hline & Myopus schisticolor & 74 & $0.35 \pm 0.02$ & 54 & $0.35 \pm 0.01$ & \\
\hline & Microtus oeconomus & 129 & $0.32 \pm 0.02$ & 51 & $0.29 \pm 0.02$ & \\
\hline & Sorex caecutiens & 56 & $0.17 \pm 0.02$ & 11 & $0.15 \pm 0.02$ & \\
\hline \multirow{2}{*}{ Mountain taiga } & Clethrionomys rutilus & 41 & $0.38 \pm 0.01$ & 27 & $0,29 \pm 0,02$ & $4.02(p<0.01)$ \\
\hline & Sorex caecutiens & 69 & $0.21 \pm 0.01$ & 14 & $0.17 \pm 0.02$ & $1.79 *$ \\
\hline \multirow{5}{*}{ Forest-tundra } & Clethrionomys rutilus & 36 & $0.37 \pm 0.01$ & 48 & $0.33 \pm 0.01$ & $2.83(p<0.01)$ \\
\hline & Clethrionomys rufocanus & 10 & $0.43 \pm 0.03$ & 24 & $0.37 \pm 0.02$ & $1.66^{*}$ \\
\hline & Myopus schisticolor & 26 & $0.45 \pm 0.01$ & 147 & $0.37 \pm 0.03$ & $2.53(p<0.05)$ \\
\hline & Microtus oeconomus & 118 & $0.42 \pm 0.02$ & 90 & $0.35 \pm 0.02$ & $2.47(p<0.05)$ \\
\hline & Sorex caecutiens & 134 & $0.20 \pm 0.01$ & 11 & $0.17 \pm 0.01$ & $2.12(p<0.05)$ \\
\hline
\end{tabular}

* $t$-Test value lesser than 1.98 means the differences are not statistically significant.

In the northern red-backed vole, we distinguished adult (overwintered) and juvenile animals and additionally subdivided juveniles (using the degree of development of their molar roots) into those of ages of one, two, and three to four months. Within the taiga zone, despite the significant differences in the location of the studied regions, OFAM levels in the northern red-backed vole were similar, and OFAM levels in juveniles in all cases were higher than in adults. In addition, it was found that the juvenile group was not always uniform in the FA level. Its magnitude itself, and the extent of the differences between the age groups, vary by region. The lowest values were registered in the middle taiga in Central Yakutia. There, OFAM in adults was low, the differences with juveniles were not significant, and within the group of juveniles no significant difference in the occurrence of asymmetry manifestations was found (Figure 6). At the same time, in the harsher conditions of the Verkhoyan'e mountains (at the elevation of 800-1000 m), not only is the difference between juvenile and adult individuals expressed more clearly, but also within the group of juveniles there is a tendency for the OFAM to decrease with age, and the differences between juveniles and adults reach statistically significant levels, with the Student's $t$-test, $p<0.05$ (Figure 6). Although for each of the three regions, for which we have differentiated data on FA levels in juveniles of the northern red-backed vole from different age groups, no significant difference in pairwise comparison of the juvenile groups was found. A regression analysis of all data showed a significant dependence of OFAM on individual age (the regression coefficient $0.73, p<0.001$ ).

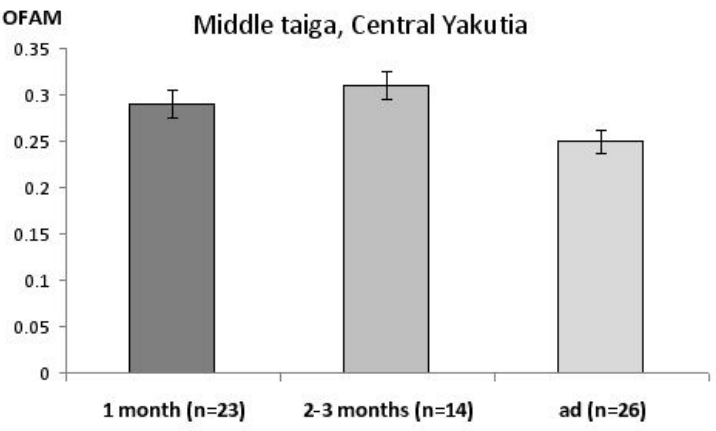

(a)

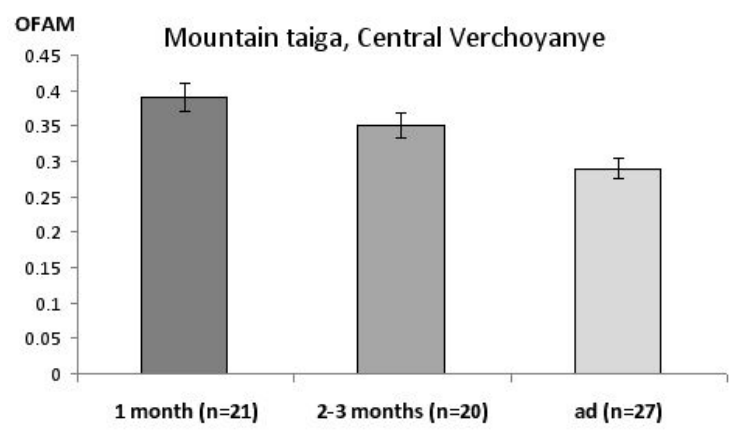

(b)

Figure 6. Age differences in asymmetry manifestations in the northern red-backed vole in the middle (a) and in the mountain; (b) taiga zone. 
The examined populations at the time of our study were characterized by similar abundance levels, so the age-related differences between them can be attributed to differences in the climatic conditions of the regions. Regression analysis of combined data on variability in the FA level in small mammals in the studied regions demonstrated that a rather significant contribution to its dependence on environmental factors is made by the age of the individual (the regression coefficient is $0.35, p<0.001$ ). However, as mentioned above, an important contribution to the dependence comes from the impact of the climate and geographic range. Statistically significant differences in OFAM values were also observed when the data were analyzed using non-parametric statistics $(p<0.05)$. In our opinion, the data presented above suggest that there are age-related differences in the occurrence of asymmetry manifestations: in juvenile small mammals its value, as a rule, is higher than in adults. The extent of the differences between the juveniles of different ages is greater in harsher climatic conditions.

\subsubsection{Changes in FA Level within One Generation Lifetime}

In the previous cases, when examining age-related differences in the FA level, we examined the data collected within one summer, which means we compared the FA level of overwintered individuals and that of their offspring. Changes in FA level within one generation can be seen in the example of the wood lemming in the forest-tundra (Figure 7). During the three years of research at the same site, the OFAM in adult individuals was lower than in juveniles. The interannual differences in the FA level observed within both adult and juvenile groups are explained, apparently, by different abundance levels: in the summer of 1987 it was a population peak, and in 1988 a sharp decline followed, which gained momentum in 1989. As we mentioned above, there is information in the literature that testifies to the developmental stability decreasing as a result of social stress [5,27]. Nevertheless, in each case, within one reproductive season, the FA level in juvenile individuals is statistically significantly higher than in adults.

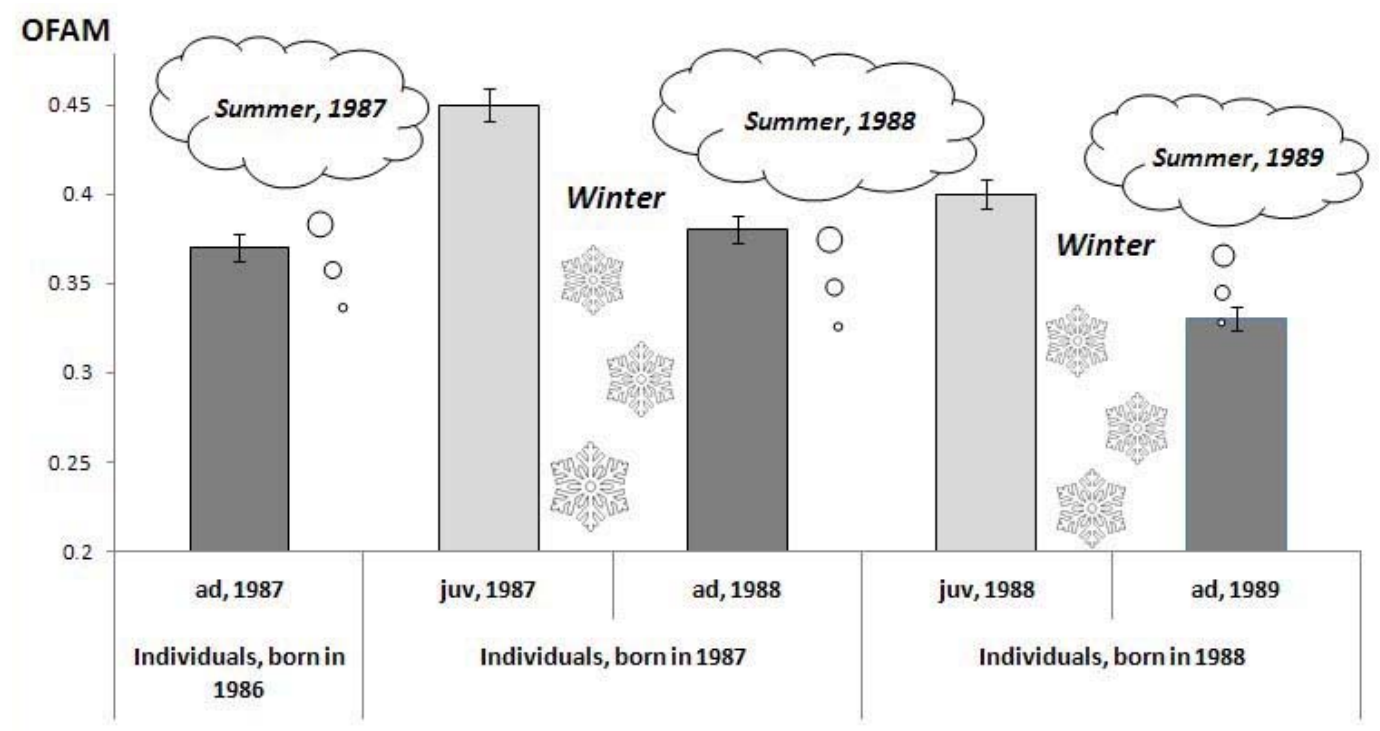

Figure 7. Changes in FA levels in the wood lemming following the overwintering.

It is necessary to take into account that the juveniles born in 1987 and the adults in 1988 represent the same generation. As one can see, the average FA level for the generation decreases following the overwintering, the statistical significance of that being high $(p<0.001)$. For our analysis we used features with phenotypic expressions which are not subject to age-related variability [47]. Therefore, we believe that the age-related differences in the occurrence of asymmetry manifestations as a criterion of developmental stability may be due to different elimination rates. It can be assumed that the high occurrence of FA manifestations, while not compromising individual viability by itself, is a kind of a marker of other disorders, which results in more severe selection among the "asymmetric" 
individuals. This assumption is also confirmed by the fact that, among the small mammals and insects, "asymmetric" individuals are more vulnerable to elimination by predators [42,43].

The intensification of juvenile reproduction in the north is one of the necessary conditions for maintaining the population size, as low spring abundance (because of increased mortality during the winter) [46] creates certain difficulties for the reproduction of the population. At the same time, increased mobility of the males involved in reproduction and high energy expenditures for carrying and nourishing the offspring in females lead to an increased elimination in first generations of small mammals; as a result, the population that enters the winter consists almost exclusively of non-breeding animals. Therefore, it is interesting to look at how the impact of the reproduction affects the average developmental stability figures.

Consideration of the materials collected in different periods showed that the occurrence of asymmetry manifestations in small mammals, as a rule, was different in the groups of breeding and non-breeding animals. For example, in the northern red-backed vole of the Southern Yakutia, when low reproductive activity of juveniles was observed, virtually no difference in FA levels between one- and two- to three-month-old individuals was found (Figure 8); and with high reproductive activity, the differences between the animals of different ages collected in late summer were very significant (Figure 8). Perhaps this is explained by the intense participation of juveniles in reproduction: in late summer, in animals of two months of age that participated in reproduction, their FA level was 0.33 , whereas in their immature peers it was 0.36 . It is necessary to take into account that these differences can be called a tendency and do not reach a statistically significant level. However, it has been known that in northern populations of small mammals, the elimination of juvenile individuals during the summer is mainly associated with animals involved in reproduction [46]. We can assume that the taxing energy expenditures on reproduction lead to the intensive elimination of individuals characterized by disturbances in developmental stability, which are reflected in an increased FA level. In that case, the average FA level in the groups that were not involved in reproduction will change during the summer much less because they are, to a lesser extent, subject to selection pressure.

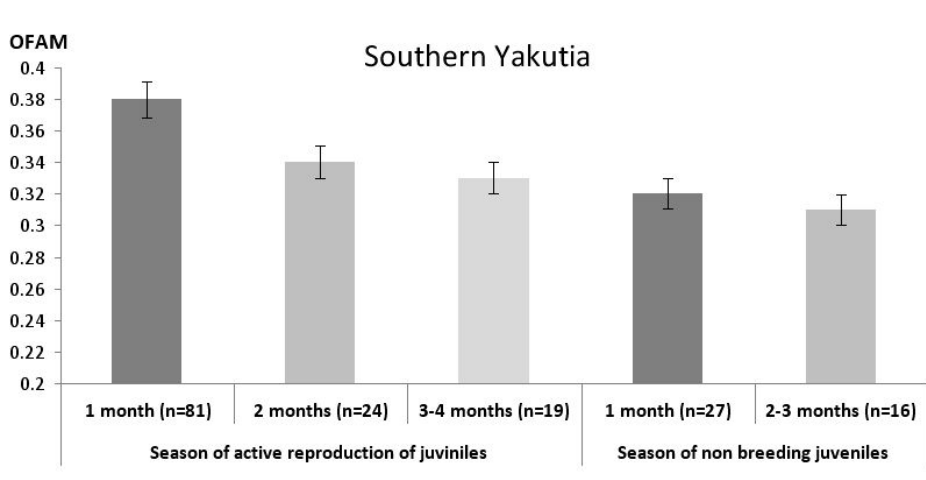

(a)

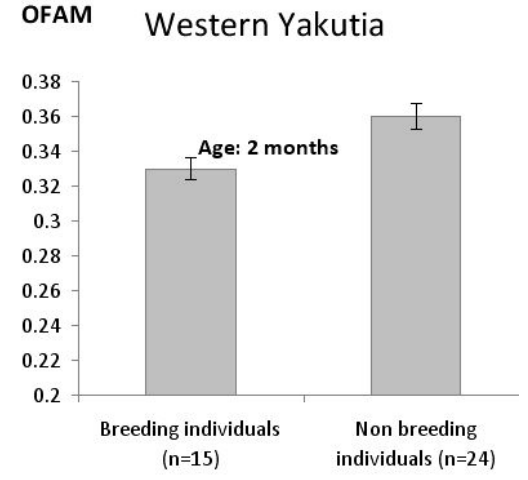

(b)

Figure 8. Comparison of FA levels in breeding and non-breeding juveniles of the northern red-backed vole in the Southern Yakutia (a); an Western Yakutia (b).

\section{Conclusions}

The level of FA in cranial features of small mammals (orders Insectivora and Rodentia) was analyzed using mass species (the northern and grey red-backed voles, the root vole, the wood lemming, and Laxmann's, tundra, and Siberian large-toothed shrews) as an example. The differences in OFAM levels between Microtina and Soricidae that were registered are explained by the differences in the skull structure, which dictated taking different complexes of features for evaluation of the FA level. It was found that, provided that their abundance levels and roles in the community were similar, the examined species are characterized by comparable OFAM values in rather vast territories of the taiga 
zone. On the ecological periphery of the range of taiga species, a severe pressure of abiotic factors leads to an increase in the occurrence of disorders of developmental homeostasis and is reflected in the increased FA level, which indicates an increased tension in the organism-environment relationship.

We suppose that similar FA levels in a significant part of even very vast geographic ranges indicate that natural selection maintains a certain level of developmental homeostasis, which is necessary for population existence. In conditions that are close to optimal, populations are relatively homogeneous in FA level, and when conditions deteriorate, an increase in the occurrence of disturbances in developmental stability is observed which leads, on one hand, to higher average FA levels for the population and, on the other hand, to heterogeneity of the population in this parameter.

The analysis of intrapopulation variability in OFAM in small mammals demonstrates that asymmetry manifestations are equally likely to occur in males and females. Any population is characterized by the presence of animals with different FA levels but, on the whole, OFAM values in juveniles are higher than in adults. The existence of differences in FA levels between juvenile and adult individuals within the same population indicates that there is a differentiated probability of elimination of individuals with increased occurrences of disturbances in developmental stability during the winter, and it is more pronounced in peripheral populations. Additionally, among the juveniles, relatively low FA levels are characteristic of individuals that reproduced. Supposedly, this is a consequence of increased mortality in individuals with developmental stability disturbances during the period of high energy expenditures with respect to reproduction. Thus, the risk of elimination of individuals with an increased FA level rises in stressful periods of life within the population.

Acknowledgments: We thank the students and postgraduates who, over a number of years, took part in the collection and processing of the material: Vitalii Danilov, Gennadii Sapozhnikov, Denis Shadrin, Marina Ushakova, Nelli Burtseva, Galina Efimova. We are also grateful to Fedor Yakovlev, who provided the material collected in the mountains of the Central Verkhoyan'e.

Author Contributions: Elena Shadrina and Yakov Vol'pert conceived and designed the experiments, performed the experiments, analyzed the data and wrote the paper in collaboration.

Conflicts of Interest: The authors declare no conflict of interest. The founding sponsors had no role in the design of the study; in the collection, analyses, or interpretation of data; in the writing of the manuscript, and in the decision to publish the results.

\section{References}

1. Van Valen, L. Study of fluctuating asymmetry. Evolution 1962, 16, 125-146. [CrossRef]

2. Leary, R.F.; Allendorf, F.W. Fluctuating asymmetry as an indicator stress: Chance use in protect nature. Acta Zool. Fenica 1989, 4, 214-217.

3. Parsons, P.A. Fluctuating asymmetry: An epigenetic measure of stress. Biol. Rev. 1990, 65, 131-145. [CrossRef] [PubMed]

4. Parsons, P.A. Fluctuating asymmetry: A biological monitor of environmental and genomic stress. Heredity 1992, 68, 361-364. [CrossRef] [PubMed]

5. Zakharov, V.M.; Zhdanova, N.P.; Kirik, E.F.; Shkil', F.N. Ontogenesis and Population: Evaluation of Developmental Stability in Natural Populations. Russ. J. Dev. Biol. 2001, 32, 336-351. [CrossRef]

6. Palmer, R.A.; Strobeck, C. Fluctuating assymmetry: A measurement, analysis, patterns. Annu. Rev. Ecol. Syst. 1986, 17, 391-421. [CrossRef]

7. Zakharov, V.M. Animal Asymmetry: Population-Phenogenetic Approach (Asimmetriya Zhivotnykh: Populyatsionnofenogeneticheskii Podkhod); Nauka: Moscow, Russia, 1987; p. 216. (In Russian)

8. Graham John, H.; Raz, S.H.; Hel-Or, H.; Nevo, E. Fluctuating Asymmetry: Methods, Theory, and Applications. Symmetry 2010, 2, 466-540. [CrossRef]

9. Markow, T.A.; Ricker, J.P. Developmental stability in hybrids between the sibling species pair, Drosophila melanogaster and Drosophila simulans. Genetica 1991, 84, 115-121. [CrossRef] [PubMed]

10. Alibert, P.; Renaud, S.; Dod, B.; Bonhomme, F.; Auffray, J.C. Fluctuating asymmetry in the Mus musculus hybrid zone: A heterotic effect in disrupted coadapted genomes. Proc. R. Soc. Lond. B 1994, 258, 53-59. [CrossRef] [PubMed] 
11. Auffray, J.-C.; Alibert, P.; Renaud, S.; Orth, A.; François Bonhomm, F. Fluctuating asymmetry in Mus musculus subspecific hybridization. In Traditional and Procrustes Comparative Approach, Advances in Morphometrics; Marcus, L.F., Corti, M., Loy, A., Naylor, G.J.P., Slice, D.E., Eds.; Plenum Press: New York, NY, USA, 1996; pp. 275-283.

12. Hosken, D.J.; Blanckenhorn, W.U.; Ward, P.I. Developmental stability in yellow dung flies (Scathophaga stercoraria): Fluctuating asymmetry, heterozygosity and environmental stress. J. Evol. Biol. 2000, 13, 919-926. [CrossRef]

13. Fowler, K.; Whitlock, M.C. Fluctuating asymmetry does not increase with moderate inbreeding in Drosophila melanogaster. Heredity 1994, 73, 373-376. [CrossRef] [PubMed]

14. Zakharov, V.M.; Sikorski, M.D. Inbreeding and developmental stability in a laboratory strain of the bank vole Clethrionomys glareolus. Acta Theriol. 1997, 4, 73-78. [CrossRef]

15. Borisov, V.I.; Valetsky, A.V.; Dmitrieva, I.L.; Krushinskaya, N.L.; Zakharov, V.M. Inbreeding and outbreeding impact on developmental stability of laboratory rat Rattus norvegicus. Acta Theriol. 1997, 4, 67-72. [CrossRef]

16. Valentine, D.W.; Soule, M. Effect of p,p'-DDT on developmental stability of pectoral fin rays in the grunion Leuresthes tenuis. Nat. Mar. Fish. Serv. Fish. Bull. 1971, 71, 921-925.

17. Pankakoski, E.; Koivisto, I.; Hyvärinen, H. Reduced developmental stability as an indicator of heavy metal pollution in the common shrew Sorex araneus. Acta Zool. Fenn. 1992, 191, 137-144.

18. Graham, J.H.; Roe, K.E.; West, T.B. Effects of lead and benzene on developmental stability of Drosophila melanogaster. Ecotoxicology 1993, 2, 185-195. [CrossRef] [PubMed]

19. Borisov, V.I.; Baranov, A.S.; Valetsky, A.V.; Zakharov, V.M. Developmental stability of the mink Mustela vison under the impact of PCB. IBID 1997, 4, 17-26. [CrossRef]

20. Allenbach, D.M.; Sullivan, K.B.; Lyary, M.J. Higher Fluctuating asymmetry as a measure of susceptibility to Pesticides in fishes. Environ. Toxycol. Chem. 1999, 18, 899-905. [CrossRef]

21. Allen, D.; Leamy, L.J. Effects of 2,3,4,8-tetrachloro-p-dioxin on directional and fluctuating asymmetry of mandible characters in mice. Ecotoxicology 2001, 10, 167-176. [CrossRef] [PubMed]

22. Michaelsen, S.A. Fluctuating Asymmetry of Menidia beryllina as a Measure of the Environmental Stress Caused by the 2010 Deepwater Horizon Oil Spill. Bachelor's Thesis, The University of Southern Mississippi, Hattiesburg, MS, USA, 2013; p. 114. Available online: http:/ /aquila.usm.edu/honors_theses/114 (accessed on 14 July 2016).

23. Chubinishvili, A.T. Homeostasis in the populations of marsh frog (Rana ridibunda Pall) living in conditions of chemical pollution in the area of the Middle Volga. Russ. J. Ecol. 1998, 1, 71-74. (In Russian)

24. Estes, E.C.; Katholi, C.R.; Angus, R.A. Elevated fluctuating asymmetry in eastern mosquitofish (Gambusia holbrooki) from a river receiving paper mill effluent. Environ. Toxicol. Chem. 2006, 25, 1026-1033. [CrossRef] [PubMed]

25. Shadrina, E.G.; Vol'pert, Y.L. Developmental Instability of the Organism as a Result of Pessimization of Environment under Anthropogenic Transformation of Natural Landscapes. Russ. J. Dev. Biol. 2014, 45, 117-126. [CrossRef]

26. Zhelev, Z.M.; Popgeorgiev, G.S.; Arnaudov, A.D.; Georgieva, K.N.; Mehterov, N.H. Fluctuating Asymmetry in Pelophylax Ridibundus (Amphibia: Ranidae) as a Response to Anthropogenic Pollution in South Bulgaria. Arch. Biol. Sci. 2015, 67, 1009-1023. [CrossRef]

27. Zakharov, V.M.; Demin, D.V.; Baranov, A.S.; Borisov, V.I.; Valetsky, A.V.; Sheftel, B.I. Developmental stability and population dynamics of shrews Sorex in Central Siberia. Acta Theriol. 1997, 4, 41-48. [CrossRef]

28. Leary, R.F.; Allendorf, F.W.; Knudsen, K.L. Genetic, environmental, and developmental causes of meristic varitation in rainbow trout. Acta Zool. Fennica 1992, 191, 79-95.

29. Clarke, G.M.; McKenzie, J.A. Fluctuating Asymmetry as a Quality Control Indicator for Insect Mass Rearing Processes. Entomol. Soc. Am. 1992, 85, 1-6. [CrossRef]

30. Jones, J.C.; Helliwell, P.; Beekman, M.; Maleszka, R.; Oldroyd, B.P. The effects of rearing temperature on developmental stability and learning and memory in the honey bee, Apis mellifera. J. Comp. Physiol. A 2005, 191. [CrossRef] [PubMed]

31. Vishalakshi, C.; Singh, B.N. Effect of developmental temperature stress on fluctuating asymmetry in certain morphological traits in Drosophila ananassae. J. Therm. Biol. 2007, 33, 201-208. [CrossRef] 
32. Polak, M.; Kroeger, D.E.; Cartwright, I.L.; Ponce deLeon, C. Genotype-specific responses of fluctuating asymmetry and of preadult survival to the effects of lead and temperature stress in Drosophila melanogaster. Environ. Pollut. 2004, 127, 145-155. [CrossRef]

33. Siegel, M.I.; Mooney, M.P.; Taylor, A.B. Dental and skeletal reduction as a consequence of environmental stress. Acta Zool. Fennica 1992, 191, 145-149.

34. Anciães, M.; Marini, M. Ã. The effects of fragmentation on fluctuating asymmetry in passerine birds of Brazilian tropical forests. J. Appl. Ecol. 2000, 37, 1013-1028. [CrossRef]

35. Cuervo, A.M.; Restrepo, C. Assemblage and population-level consequences of forest fragmentation on bilateral asymmetry in tropical montane birds. Biol. J. Linn. Soc. 2007, 92, 119-133. [CrossRef]

36. Wojcik, J.M.; Polly, P.D.; Wojcik, A.M.; Sikorski, M.D. Epigenetic variation of the common shrew, Sorex araneus, in different habitats. Russ. J. Theriol. 2007, 6, 43-49.

37. Stige, L.C.; Slagsvold, T.; Vøllestad, L.A. Individual fluctuating asymmetry in Pied Flycatchers (Ficedula hypoleuca) persists across moults, but is not heritable and not related to fitness. Evol. Ecol. Res. 2005, 7, 381-406.

38. Bartoš, L.; Bahbouh, R.; Vach, M. Repeatability of size and fluctuating asymmetry of antler characteristics in red deer (Cervus elaphus) during ontogeny. Biol. J. Linn. Soc. 2007, 91, 215-226. [CrossRef]

39. Mateos, C.; Alarcos, S.; Carranza, J.; Sánchez-Prieto, C.B.; Valencia, J. Fluctuating asymmetry of red deer antlers negatively relates to individual condition and proximity to prime age. Anim. Behav. 2008, 75, 1629-1640. [CrossRef]

40. Naugler, C.T.; Leech, S.M. Fluctuating Asymmetry and Survival Ability in the Forest Tent Caterpillar Moth Malacosoma disstria: Implications for Pest Management. Entomol. Exp. Appl. 1994, 70, 295-298. [CrossRef]

41. Moller, A.P. Fluctuating Asymmetry in Male Sexual Ornaments May Reliably Reveal Male Quality. Anim. Behav. 1990, 40, 1185-1187. [CrossRef]

42. Muzlanov $\mathrm{Yu}, \mathrm{A}$. Otsenka sostoyaniya prirodnykh populyatsii po gomeostazu razvitiya na primere analiza raspredeleniya anomalii zhilkovaniya kryl'ev strekozy krasotki blestyashchei (Calopteryx splendens Harr). Russ. J. Ecol. 1997, 6, 442-446. (In Russian)

43. Khirevich, E.A. Strukturno-Funktsional'nyi Analiz Populyatsii Obyknovennoi Polevki v Svyazi s Problemoi Izbiratel'nosti Otlova Gryzunov Sovami; Extended Abstract of the Dissertation for the Degree of Candidate of Science (Biology); Pemskii Gosudarstvennyi Universitat: Perm, Russia, 2002; p. 24. (In Russian)

44. Johnstone, R.A. Female Preference for Symmetrical Males as a by-Product of Mate Recognition. Nature 1994, 372, 172-175. [CrossRef] [PubMed]

45. Swaddle, J.P.; Cuthill, I.C. Preference for Symmetrical Males by Female Zebra Finches. Nature 1994, 367, 165-166. [CrossRef]

46. Vol'pert, Y.L.; Shadrina, E.G. Small Mammals of the North-Eastern Siberia (Melkie Mlekopitayushchie Severo-Vostoka Sibiri); Nauka (Sib. Otdel.): Novosibirsk, Russia, 2002; p. 246, (In Russian) [CrossRef]

47. Zakharov, V.M.; Baranov, A.S.; Borisov, V.I.; Valetskii, A.V.; Kryazheva, N.G.; Chistyakova, E.K.; Chubinishvili, A.T. Zdorov'e Sredy: Metodika Otsenki (Health of the Environment: Practical Evaluation); Tsentr Ekolog; Politiki Rossii: Moscow, Russia, 2000; p. 68. (In Russian)

48. Shadrina, E.G.; Vol'pert, Y.L.; Danilov, V.A.; Shadrin, D.Y. Bioindication Impact of Mining on Terrestrial Ecosystems of the North (Morphogenetic Approach; Bioindikatsiya Vozdeistviya Gornodoby Vayushchei Promyshlennosti na Nazemnye Ekosistemy Severa (Morfogeneticheskii Podkhod); Nauka (Sib. Otdel.): Novosibirsk, Russia, 2003; p. 110, (In Russian) [CrossRef]

49. Koshkina, T.V. Metod opredeleniya vozrasta ryzhikh polevok i opyt ego primeneniya. Russ. J. Zool. 1955, 34, 631-639. (In Russian)

(C) 2016 by the authors; licensee MDPI, Basel, Switzerland. This article is an open access article distributed under the terms and conditions of the Creative Commons Attribution (CC-BY) license (http://creativecommons.org/licenses/by/4.0/). 